\title{
20. Governing the Canterbury Earthquake Recovery, 2010-2011: The debate over institutional design
}

\author{
Rachel Brookie
}

The sequence of earthquakes in Christchurch shattered its residents' preconceived notions about the location and magnitude of such events. By March 2012, Canterbury had endured more than 10000 aftershocks, of which more than 3000 were noticeable. The quakes not only shook infrastructure, buildings and people, but also governance arrangements and institutional design for recovery.

This chapter first describes the relevant impacts of these events. Second, it briefly examines literature on the governance of response to and recovery from major disasters and on community engagement in disaster recovery. Third, it describes and clarifies the country's existing framework for disaster response and recovery before the quakes. Fourth, it evaluates the evolving governance arrangements created to manage the recovery from the quakes. Finally, it discusses the inadequacies in institutional design and lessons highlighted by the quakes.

This chapter argues that the existing statutory framework for long-term recovery was inadequate. The governance arrangements created after the quakes addressed a number of concerns, but also generated problems. Future arrangements must provide an institutional framework that addresses both immediate response and adequate statutory and policy support for long-term recovery. ${ }^{1}$

\section{Background: A series of unfortunate events}

Canterbury was struck by three major, and hundreds of minor, earthquakes between 4 September 2010 and 22 February 2011. They resulted in liquefaction, damage to buildings and infrastructure, and the third major quake took 185 lives.

\footnotetext{
1 A longer version of this chapter was originally published as a working paper. It is available on the IPGS website: <http://igps.victoria.ac.nz/publications/files/27b07e4270b.pdf>.
} 
In March 2011, the Government predicted the repair work would cost NZ\$20 billion (Bollard and Ranchhod 2011). Others argued the figure could reach NZ\$30 billion (NZPA 2011). In December 2011, Treasury estimated the combined cost of the two largest earthquakes to be equivalent to about 10 per cent of GDP (Bollard and Ranchhod 2011). While all sources emphasise uncertainty surrounding their estimates, the Treasury Budget Policy Statement 2012 (Treasury 2011) stated that rebuilding Canterbury was the biggest economic undertaking in New Zealand's history, having a severe impact on government finances.

Two large aftershocks on 13 June 2011 caused further damage. Canterbury was faced with $124 \mathrm{~km}$ of damaged water mains, $300 \mathrm{~km}$ of damaged sewer pipes and 50000 road surface defects. More than 1200 central city buildings were severely damaged and more than 100000 residential houses require repair or rebuilding (CERA 2011a).

On 23 December 2011, 11 quakes of magnitude 4.0 to 6.0 resulted in further damage and liquefaction and added about NZ\$300 million to the Government's operating deficit. By mid January 2012, Canterbury had experienced 9500 quakes, an average of one quake of more than magnitude 3.0 every four hours.

This ranks as one of the most costly natural disasters for insurers worldwide since 1950 (Doherty 2011). As at December 2011, the estimated total net cost to the Crown was NZ\$13.5 billion (Doherty 2011). The Earthquake Commission (EQC), the New Zealand Government-owned provider of national disaster insurance to residential property owners, has received 156670 claims as a result of the September 2010 quake, 156543 claims as a result of the February 2011 quake, and by February 2012 received 434797 claims for all seismic events.

In summary, in mid January 2012, 500 days after the first quake, 892 buildings had been demolished and NZ\$2.78 billion in EQC claims paid out (Greenhill 2012). As at 10 February 2012, the EQC reports there have been 15 major earthquake events that allow insurance holders to make a claim. Continued seismic activity has constrained recovery activities.

\section{Looking at the Literature}

\section{Defining Response and Recovery}

The most important terms in the disaster literature are summarised as the four 'rs' - reduction, readiness, response and recovery - and are defined in the National Civil Defence and Emergency Management (CDEM) Plan. ${ }^{2}$ James Rotimi (2010) finds that the response phase is the emergency or crisis period that ends when

2 These definitions are available in James Smart's Chapter 19, this volume. 
there are no more search and rescue operations and all safety evaluations are completed. Recovery involves initiating activities after impact and extending them until the community's capacity for self-help is restored. Rotimi (2010:34) describes recovery 'as the totality of activities, carried out at the post-impact stage at some point after the initial crisis time period of disasters, to progressively reinstate damages made to every facet of a community's environment'. It starts at day one of the emergency and ends when the community's capacity for selfhelp is restored. The response and recovery phases overlap.

\section{Literature on the Governance of Major Disasters}

International literature shows that the recovery phase shares many principles with the other 'rs'. As with risk reduction and response, recovery requires an approved government policy, an enabling national system, appropriate tools and advocacy among all the actors including civil society. Decentralisation, links between local and national governments and a holistic approach to managing disasters are also needed.

The United Nations Development Programme document Post-Disaster Recovery: Guiding Principles (UNDP 2006:10) sets out appropriate institutional arrangements for recovery. Roles and responsibilities should be clearly defined within a country's broader risk reduction, disaster preparedness and contingency planning processes. Experience suggests recovery and reconstruction efforts are best mounted on existing institutional frameworks and, if necessary, enabled with faster mechanisms for recovery. If a new structure for recovery is to be put in place, its objective should be achieving cohesion, coordination and consensus among different disaster stakeholders. The new structure should focus on:

The definition of recovery/development policies, priorities and strategic guidelines, formulation/implementation/oversight of recovery proposals, monitoring of progress, establishing a permanent dialogue and consensus space with civil society, opposition parties, private sector, international cooperation agencies, donors and lending agencies, maintain transparency, accountability and good governance in the process as well as a strategic communications and information campaign. (UNDP 2006)

The document also states that the main challenge in devising an institutional arrangement for recovery and reconstruction is to find a rapid implementation mechanism that does not undermine the existing institutional framework or affect ongoing good-governance mechanisms. It also notes that in the aftermath of a major disaster, implementation capacity is a major recovery planning issue. 
Local authorities often lack the capabilities and resources to address adequate preparation for disasters and to deal with their short and long-term implications. Therefore, local authorities may require central government support, and substantial linkages must be established between local and national levels - this includes support with resources and efficient coordination achieved by collaboration.

\section{Literature on Community Engagement in Disaster Recovery}

Community involvement in recovery activities contributes beneficially to the success of long-term recovery. Engaged communities can identify 'workable solutions to the range of problems recovery presents, sharing and delegation of duties, securing community "buy in" to the process, and building trust' (Vallance 2011:20).

Some writers argue that community participation by 'deliberative methods' is more practicable in the recovery phase than in the response phase. Community panels, citizens' juries, deliberative polling, consensus conferences and planning cells ${ }^{3}$ promote high levels of community engagement in decisionmaking, bring communities together to achieve understanding of an issue or problem and find common ground that will ideally lead to a decision. Successful deliberative processes depend on three elements: influence - the process should have the ability to influence policy and decision-making; inclusion - the process should ideally be representative, inclusive and encourage equal opportunity to participate; and deliberation - the process should provide open discussion, access to information and movement towards consensus (Millen 2011). Such methods facilitate trust in governance, whatever the decision-making structure may be. They can improve effective communication and recovery outcomes as they engage local knowledge. This results in appropriate, detailed, contextual plans and policies. Millen argues deliberative methods should be embedded in recovery and community engagement processes.

Effective engagement, which aims to facilitate communities owning their own recovery, is a crucial element, integrating social, economic and environmental goals and ideals.

3 For further information on deliberative methods, see Millen (2011). 


\section{The New Zealand Disaster Response and Recovery Framework}

\section{The Response and Recovery Framework Prior to September 2010}

This section will outline the New Zealand disaster response and recovery processes - including legislation, policies and agencies - that existed prior to the Canterbury earthquakes.

The National CDEM Strategy sets out the New Zealand vision to encourage resilience, where communities understand and manage their hazards. This approach centres New Zealand's emergency management system on the community - the first level of response in the event of a disaster.

The Civil Defence and Emergency Management (CDEM) Act 2002 takes an 'all hazards, multi-agency approach' across the four rs. The Act and the CDEM strategy, plan and guide set out the structure for the management of the four rs.

The Ministry of Civil Defence and Emergency Management (MCDEM) is responsible for disaster response and recovery at a national level; however, planning for and implementation of disaster response is led at a local level through CDEM groups, which are partnerships between local authorities, fire, police, health services, government departments and lifeline utilities (such as water and power providers). CDEM groups coordinate planning programs and other activities for civil defence and emergency management, providing the basis for the integration of national and local civil defence emergency management planning and the alignment of local planning with the national strategy and plan.

Local authorities in CDEM groups must prepare for and be able to respond to disasters. CDEM groups, through local authorities, implement emergency response activities at the local level through Emergency Operations Centres (EOCs), normally located in council buildings. The Central Government intervenes when an event exceeds local capacity.

New Zealand, unlike most other Western nations, does not have specific standalone organisations that manage disasters. Nor is there a national body for disaster risk reduction that combines all sector coordination and collaboration. Instead, the disaster management system is based on day-to-day organisational responsibilities and planning together with other agencies to coordinate an approach to disasters. It is highly devolved: local authorities and their communities lead the response and recovery. 
In a large-scale disaster, coordination is managed on a continuum. The CDEM group works at the regional level, while the Officials Committee for Domestic and External Security Coordination (OCDESC) synchronises the whole-ofgovernment disaster response and recovery at the national level. The OCDESC comprises chief executives of government agencies and relevant officials and is administered by the Department of Prime Minister and Cabinet.

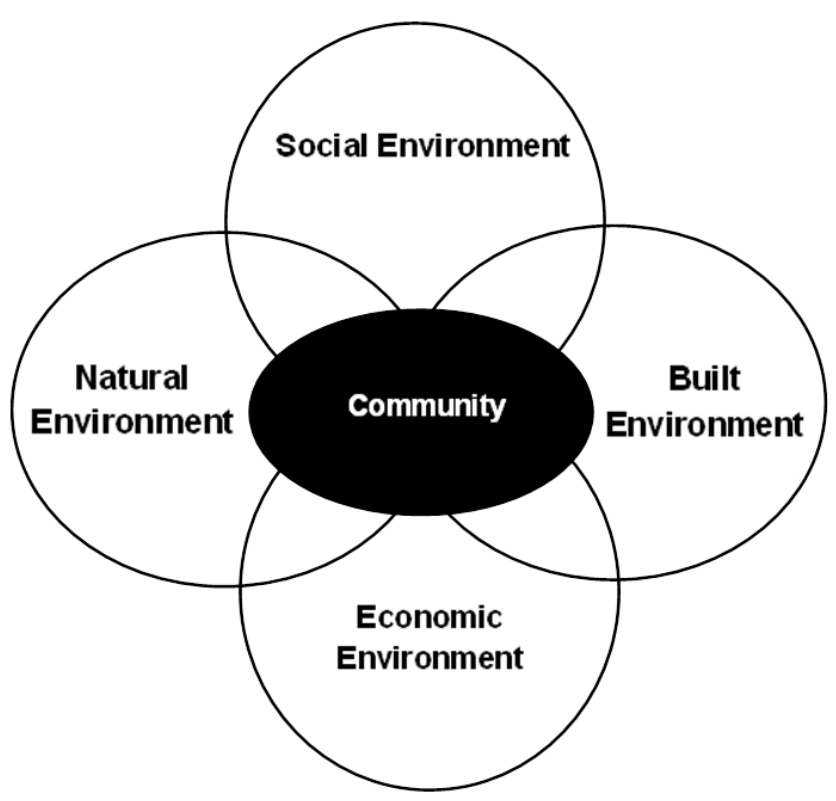

Figure 20.1 Ministry of Civil Defence and Emergency Management's 'Focus on Recovery'

Source: Ministry of Civil Defence and Emergency Management (MCDEM). 2009. Section 25. Recovery (Wellington: Government of New Zealand).

When a state of national emergency is declared, the control of emergency management operations by the director of CDEM is supported by a range of enabling powers. Powers may include: evacuating and entering premises, closing roads, giving directions, requisitioning powers, carrying out inspections and undertaking works to make roads and structures safe. The director also controls the exercise and performance of the powers of CDEM groups and group controllers. Such powers may be exercised only during a declared state of emergency, after which the provisions that enable response and some recovery activities cease to apply.

\section{Recovery}

The MCDEM's 'Focus on Recovery' outlines a holistic framework for recovery, which centres on the statement that recovery is best achieved when the affected 
community exercises a high degree of self-determination. It encompasses the social, built, economic and natural environments, integrating recovery activities with the community at the centre.

The environments are represented by task groups charged with recovery. Subtask groups may be set up for larger-scale recovery. Task groups are coordinated by a recovery manager. Communication and regular meetings between the groups and the recovery manager are crucial. Information derived from these groups should be communicated to the media and all agencies (MCDEM 2009b).

As the scale of the recovery and level of complexity increase so does the institutional response. The civil defence 'national recovery management structure' demonstrates the recovery task groups being undertaken in parallel at local, regional and national levels. These are coordinated at the readiness phase, so all actors know how to respond when an emergency occurs. In practice, central government is involved with a local response-for example, MCDEM officials are designated to assist by liaising with relevant government agencies.

The director of CDEM coordinates the recovery. This includes advising the Minister of Civil Defence of needed government assistance, providing information to the OCDESC, and preparing and implementing a 'recovery action plan'. The director coordinates activity through a national recovery manager, who will, where necessary, establish a National Recovery Office to ensure activity is coordinated and the recovery function is implemented. Other tasks of the National Recovery Office include: coordinating agencies, determining priorities and major areas of recovery, formulating recovery policies and strategies, and monitoring recovery activities.

Under the Act, recovery activity is focused on CDEM groups, but the Act empowers the MCDEM to manage recovery if the minister is satisfied the CDEM group cannot manage on its own. A recovery coordinator may also be appointed to manage the work of agencies and ensure that government assistance and actions are coordinated. The recovery coordinator, appointed for up to 28 days, will be responsible to, and funded by, the Director of Civil Defence.

In an emergency the CDEM Group Recovery Manager coordinates the recovery activity in the region. The Local Recovery Manager, who may be appointed indefinitely, coordinates the recovery activity in a particular local authority area with the CDEM Group Recovery Manager. Tasks and responsibilities for all of these actors are outlined in the guide to the National CDEM Plan (MCDEM 2009a).

\section{Community Engagement}

CDEM community engagement best-practice documents acknowledge that effective recovery programs depend on the number of competent people 
involved. CDEM documents explain that the context of the disaster provides for the designation of the level and process of engagement. The response will depend on the nature of the task, the type and impact of the disaster, and the affected community (MCDEM 2010). While effective engagement in disaster recovery management includes public meetings, community representation and inclusion of representatives from community organisations in decision-making, public participation in New Zealand after disasters generally takes the form of consultation - a low level of public engagement. The EQC, a crown entity, is also involved by providing natural disaster insurance cover to those who have home and/or contents insurance. Funded through a levy, the EQC covers up to NZ\$100 000 for damage to dwellings, and up to NZ\$20 000 for damage to contents. Private insurers pay the residual amount. The EQC also provides limited cover for damage to residential land. Land cover is unique internationally.

Disasters and recovery involve other legislation and regulations in New Zealand. The Building Act 2004 governs the construction of new buildings and alteration and demolition of existing buildings. The Resource Management Act (RMA) 1991 designates management of the environment.

\section{Criticism of the Pre-Earthquake Recovery Framework}

New Zealand has effective, modern and well-resourced emergency services for dealing with small-scale localised emergencies, but has significant gaps and deficiencies with respect to dealing with nationally significant disasters.

Rotimi (2010), indicating that practical problems in legislation could constrain recovery, focused on the inadequacy of statutory powers to coordinate recovery. Only months before the first quake, he outlined deficiencies in the recovery legislation and supporting framework.

1. The CDEM Act addresses recovery only during the state of emergency.

2. There are likely to be resource shortages during recovery.

3. Institutional capacity mandated in recovery activities is concerning, and local councils' duties and obligations during an emergency and recovery are unclear.

4. The CDEM Act covers only the first 28 days of a recovery, and is confusing about responsibility for reconstruction/recovery. The powers of the appointed recovery coordinator should extend beyond a declared emergency period.

5. It is difficult to understand who coordinates reconstruction and how this is done.

6. A strict implementation of the EQC Act could prevent property owners from receiving damage compensation-for example, the EQC may refuse compensation if a building is on land notified as subject to natural hazards. 
7. Strict application of the $R M A$ would slow recovery and consent applications would overwhelm local councils' capabilities.

In summary, in an emergency, the existing model for disaster recovery in New Zealand envisaged that the MCDEM had extra short-term powers to enact response and early recovery activities. Long-term recovery was not supported by legislative powers. Local authorities - through CDEM groups - would have to lead the recovery.

Rotimi concluded that though the statutory basis for the coordination of recovery activities was under government review, it was inadequate.

\section{Looking at Recovery}

The following sections outline the debate surrounding, and the results of, the governance arrangements following the earthquakes.

\section{September 2010: A local emergency}

A state of local emergency was declared initially by the mayors of Christchurch City, Selwyn District and Waimakariri District. It permitted actions unavailable in normal circumstances, including suspending normal and essential services.

In Wellington, the MCDEM activated the National Crisis Management Centre (NCMC) where the National Director of Civil Defence coordinated the response to the earthquake. CDEM groups in Christchurch, Waimakariri and Selwyn implemented response activities and were expected to lead the recovery.

The EQC received 156670 claims for damage to houses and land. Unsafe buildings were cordoned off and an overnight curfew was established for parts of Christchurch City. Up to 75 per cent of the city's power was disrupted by the quake, but 90 per cent had been restored on the same day. Citycare ${ }^{4}$ connected as many water connections in three days as it would normally do in a year.

Gerry Brownlee was appointed the minister responsible for the Christchurch earthquake recovery, leading a cabinet committee on Canterbury reconstruction to coordinate the Government's response. On the day before the state of emergency ended, the Government introduced the Canterbury Earthquake Response and Recovery (CERR) Bill. It would enable the Executive to use orders-in-council ${ }^{5}$ to amend almost all legislation, if needed, to respond to and recover from the earthquake. The Bill also established the Canterbury Earthquake Recovery

\footnotetext{
4 A provider of maintenance and management services across New Zealand's infrastructure.

5 An order-in-council is made without the approval of Parliament, allowing legislative changes to be made and assented to quickly.
} 
Future-Proofing the State

Commission (CERC) to advise ministers about proposed orders-in-council and to liaise between central and local governments. The Canterbury Earthquake Response and Recovery (CERR) Act was passed with multi-party support and without select committee examination.

The CERR Act allowed amendments to legislation that were required to ensure 'that the Government has adequate statutory power to assist with the response to the Canterbury earthquake' until the state of emergency was lifted (Government of New Zealand 2010). When the state of emergency was lifted all special powers accorded to the MCDEM would expire and routine procedures would resume.

CERC was established, consisting of the three local mayors, a regional council (Environment Canterbury) representative, an engineer and the former directorgeneral of the Ministry of Agriculture and Forestry as chair.

\section{The Recovery from the September Earthquake}

Within two days the CDEM recovery mechanisms were up and running. Leaders had been appointed for the social, built, economic and natural environments, reporting to a designated coordinating executive group (Dalziel 2011). Despite this, and despite the wideranging powers the Act provided, local people within months complained that the recovery process had stalled.

Lianne Dalziel, a Christchurch MP, attributed slow progress to inadequate processes, undue haste and lack of rigorous scrutiny during the creation of the Act and CERC. CERC, intended only as an advisory group, created confusion over to whom the leaders of the recovery functions were reporting and who was in charge of the overall recovery. The Christchurch City Council (CCC) did not, as recommended in the CDEM recovery plan, appoint a recovery manager to focus on coordination and communication, nor did it develop recovery planning processes (Dalziel 2011).

Before the earthquake, Christchurch City mayor Bob Parker faced a serious challenge to re-election and voters expressed dissatisfaction with the performance of the council and its chief executive. After the earthquake Parker displayed exactly the communication skills needed to reassure the citizens and was re-elected.

In October the recovery phase was under way and the CDEM framework called for leadership, coordination and steering from the CCC, which should at the same time resume 'business as usual'. The CCC resumed business-as-usual processes, which effectively stalled recovery activities by, for example, not fast-tracking consents for rebuilding. Many argued there was no visible engagement from the CCC with the public over how recovery should be handled, and it left the EQC and CERC to take charge. 
In contrast, the Selwyn and Waimakariri district councils placed community engagement at the core of all decision-making and communication (Dalziel 2011). Before the quake they had active and well-funded community boards. Shortly after the earthquake, a hub office for Waimakariri was set up, with agencies involved in the recovery establishing offices there. This enabled the recovery agencies to know the situation on the ground and residents to get information. Waimakariri community engagement was seen as successful. In comparison it took until mid November 2010 for the CCC to hold the first 'community meetings', by which time the lack of communication angered residents. With CERC lacking capacity for action, and the CCC failing to develop recovery plans, the recovery process ground to a halt. By the time of the February quake, residents, MPs and business owners demanded the Minister for Earthquake Recovery use his powers under the CERR Act to speed up the recovery.

\section{Rethinking the Framework for Recovery Following the February 2011 Earthquake}

A state of local emergency was again declared immediately after the earthquake on 22 February 2011. Then, on 23 February, New Zealand's first state of national emergency was declared. This empowered the Director of Civil Defence to direct the response on a national basis, mostly from Christchurch. National and international teams joined the local CDEM groups in the search for survivors.

With the CBD cordoned off and damage to homes and infrastructure across the city, the state of national emergency remained until 30 April 2011. By then, the Government had implemented new governance arrangements to meet the scale of the disaster. Whole hillsides had slipped away, liquefaction reappeared and many roads were impassable.

Lessons had been learned after the September earthquake: recovery was a long-term activity that needed to commence quickly, and could not be just about infrastructure - social and economic contexts were equally, possibly more, important. The Government also considered lessons from international experience, where status-quo arrangements were insufficient to cope with major disasters and a new authority was needed to lead the recovery effort. The Government noted no single existing central or local government agency at that time had the powers to manage the recovery, nor was the CERR Act framework sufficient for long-term recovery.

The Canterbury Earthquake Recovery Act 2011 (CER Act) was introduced, and passed by Parliament under urgency on 14 April, after a one-day select committee process. The Act extended the Executive's power to modify legislation through orders-in-council to five years. It disbanded CERC, replacing 
it with the Canterbury Earthquake Review Panel as the advisor to the minister. It created a new government department, the Canterbury Earthquake Recovery Authority (CERA), to report to the Minister for Earthquake Recovery. CERA was to lead and coordinate the recovery efforts of the three councils, Environment Canterbury, central government departments and crown entities, infrastructure providers, business, construction firms and the local community.

CERA had the power to decide reconstruction priorities, compulsorily acquire land, enter premises, undertake works and demolish and dispose of dangerous buildings. CERA, given a five-year mandate, began operations with the Deputy State Services Commissioner as interim head. On 13 June, the former head of the electricity distribution network Orion took over as CEO. The 2011 budget allocated NZ\$25.5 million over two years to set up CERA. An additional NZ\$5.5 billion was committed over six years for the Canterbury Earthquake Recovery Fund.

The cabinet paper Proposed Governance Arrangements (Government of New Zealand 2011a) noted that departments are the default option for the governance of functions and powers requiring a high degree of ministerial control, including where there is exercise of the significant coercive powers of the state. Officials argued that the departmental form would have 'a leadership structure that is able to act decisively and quickly and be closely aligned with the Government's priorities' (Government of New Zealand 2011a). Officials decided against establishing an advisory board, which would impact on the clear line of accountability from the CEO to the minister.

CERA was given nine months to create a recovery strategy as a road map for effective, timely and well-coordinated recovery for Greater Christchurch. The CCC was tasked with developing a recovery plan for the Christchurch CBD, to be signed off by the minister.

The Minister for Earthquake Recovery has extensive powers to coordinate activity needed to effect the recovery and oversee policy and legislative process. Under the CER Act, a four-person independent review panel advises the minister.

The CER Act also mandated a community forum to provide information and advice to the minister on earthquake recovery matters, meeting at least six times annually. International experience reinforced the importance of community engagement during the recovery, and the forum would give the opportunity for the minister 'to encourage meaningful participation by community representatives in the process' (Government of New Zealand 2011a). While the Act suggested 20 members, the minister appointed 38 from a cross-section of the Canterbury community, representing business and ethnic interests, as well as residents' associations and groups. An eleventh-hour change in Parliament made CERA subject to the Official Information Act. 


\section{Key Issues: Governance}

Despite cabinet papers citing international best practice of instituting a layer of governance between the authority and the politicians, CERA was made a government department. The Government considered an alternative option to set up CERA as an independent crown entity. Crown entities normally have an arm's-length relationship with ministers but cabinet preferred a strong relationship between the minister and CERA and strong coordination across portfolios and agencies embodied in the departmental form (Government of New Zealand 2011a). Additionally, it seems likely that cabinet wanted the whole process directly driven by a minister, given the political and fiscal risks involved; however, this approach raised the risk of political priorities driving aspects of the recovery rather than the needs of the affected communities.

Professor Bruce Glavovic, the Massey University holder of the Earthquake Commission chair in natural hazards planning, expressed concerns that instead of following best practice CERA was 'untried, untested'; New Zealand was 'inventing their own recipe' (McCrone 2011).

Although the CDEM mechanism was bypassed by the introduction of CERA, the CER Act mirrors the 'holistic' approach advocated in the MCDEM literature, being centred on the four environments mentioned earlier.

\section{Reflecting on Rotimi's Concerns}

Several of Rotimi's concerns about the adequacy of the statutory and regulatory framework to manage disaster recovery have been realised. Government inaction before the earthquakes has now been addressed for Canterbury only by CERA.

First, the problem that the CDEM Act enables statutory powers only for shortterm recovery, during the declared state of emergency, was addressed by CERA, which empowered recovery activities for five years.

Rotimi's second concern - that there are likely to be shortages of resources during recovery - is hard to determine at this early stage of rebuilding. The reality is that extensive rebuilding is just beginning. The Government has acknowledged that there are skills shortages in the construction industry. Third, Rotimi suggested the institutional capacities of local councils in recovery activities would be insufficient. These concerns, evident in Christchurch post September 2010, have arguably increased since February 2011. The CCC's institutional capacity has been diminished by flawed relationships, ineffective processes and political infighting. The communication procedures and management of the CCC have become a major issue, generating significant protest action.

There were calls for the councillors to be replaced with government-appointed commissioners. At the end of February 2012, the CCC was operating with a 
crown observer to help the council address governance issues and ensure it functions well enough to support the recovery. The crown observer introduced another layer of central government involvement into the governance of council business, but was made with the agreement of the council.

Rotimi's fourth concern - of confusion over who should take charge during reconstruction and recovery - has been addressed by the clear reporting lines provided in the CER Act. All roles and responsibilities designated after the state of emergency was lifted are available on the CERA and CCC websites. The CCC is responsible for the Central City Plan, which was well received by the public. CERA is responsible for the recovery strategy document, policy, planning and the majority of work in Christchurch to date: demolitions. CERA also has overall control of the direction of the recovery, for which the most important decisions are made by the Minister of CER and cabinet. The CER Act gave the minister the ability to suspend, amend, cancel or delay any council plans and policies, which must be consistent with CERA's recovery strategy and be signed off by the minister.

The role of the CCC in the recovery effort with CERA could have been neglected. In its comment on the draft recovery strategy of October 2011, the CCC was 'concerned that appropriate governance arrangements have yet to be established to ensure that recovery activities are integrated and well-coordinated and that decisions are made with the right level of input from others' (CCC 2011). The CCC acknowledged CERA had the lead role; however, the CCC did not think it was appropriate that the council did not have a governance role in the preparation of the draft strategy (CCC 2011).

Fifth, Rotimi's concerns about the coordination of recovery activities have been addressed by CERA, which is responsible for coordination and planning for infrastructure, economic recovery and the welfare rebuild. Again, the CCC (2011) had concerns, calling for greater clarity about how recovery work and decisions should be coordinated in CERA's recovery strategy, and asked that the affected local authorities be involved in the development of each recovery plan. This tends to support media reports and blog comments that some residents feel the major recovery actors are not communicating and coordinating their activities with one another and so are hindering recovery.

The coordination of reconstruction has been addressed by the EQC awarding Fletcher Construction a bulk contract for rebuilding approximately 50000 moderately or seriously damaged properties. This means residents do not have to compete for the services of a limited number of building contractors, but now compete for attention within the Fletcher organisation. 
Rotimi's sixth concern, about the inadequacies of the EQC Act, has been realised. The EQC Act had not envisaged multiple events within such a short time (Cowan and Simpson 2011). As at 10 February 2012, the EQC had dealt with 15 claimable events.

In September 2011, the EQC and the Insurance Council sought a declaratory judgment in the High Court as to whether EQC liability would be limited to NZ\$100 000 for claims relating to an aggregate of events, or whether its cover would reinstate after each major quake. The court found that EQC cover (and therefore its liability of up to NZ\$100 000) would reinstate after each major quake. This decision provided certainty, but it also added a large amount of liability to the Government.

Due to the unforeseen 'widespread and locally catastrophic liquefaction' (Cowan and Simpson 2011), EQC liability for restoration of the land in Canterbury has become much more complex, involving complicated engineering and legal considerations not anticipated when the EQC Act was passed. Decisions about zoning and the future designation of properties have become much more difficult and time-consuming.

There has been concern at the slow rate of EQC settlements. As at mid February 2012, 85794 EQC claims from all events, including aftershocks, had been resolved.

Insurance has been the most urgent and significant issue holding back the progress of recovery. The continual sequence of aftershocks has made rebuilding decisions much harder. The susceptibility to risk of liquefaction in some areas added to this uncertainty.

EQC cover applies only when property owners are insured, and there are problems with the availability and pricing of earthquake cover as well as concerns about slow payouts from private insurers. Insurers able to arrange reinsurance cover are finding that costs have increased as much as four or five times (Grant 2011). As the increased cost to insurers is largely being passed on to consumers, earthquake insurance may become increasingly unavailable and unaffordable.

The quakes have wiped out the NZ\$6 billion reserve of the Natural Disaster Fund, which underpins the EQC. The Government provided back-up financial support for AMI when it seemed the costs of the quakes might exceed AMI's reinsurance and reserves. Business interruption insurance has been crucial for many businesses' survival, but for most businesses this insurance ran out on 22 February 2012.

Seventh, Rotimi was concerned that a strict application of the Resource Management Act would slow the recovery. The RMA was amended by orders- 
in-council under both the CERR Act and the CER Act. These orders eased time frames for approval of consents by councils and introduced a range of amendments to address specific problems, such as faster resource consent processes to allow repairs to electrical system damage. Rotimi noted that consent applications would overwhelm local councils' capabilities during any post-disaster recovery. While it is unclear if this has happened, the CCC (2012) announced an additional 69 full-time staff to deal with consent issues. The real surge on consents will occur when rebuilding starts in earnest.

CERA has responsibility for zoning of land designated as 'green', 'orange', 'red' or 'white'. As at June 2011, the residential green zone contained around 100000 homes that, subject to some further investigation about liquefaction risk, could begin the repair/rebuild process. Repair/rebuild of about 10000 homes in the residential orange zone was on hold pending further assessment. The residential red zone contained about 5000 homes, many built on land prone to liquefaction, where remediation was judged likely to be 'prolonged and uneconomic'. In June 2011, the Government announced it would offer to buy out red-zoned insured residential homes at recent rateable value. The cost of the buyout was estimated to be between NZ\$485 and NZ\$635 million, which would come out of the NZ\$5.5 billion earthquake recovery fund. As at February 2012, some homeowners were yet to hear the fate of their properties.

\section{Community Engagement}

Community engagement was at the centre of recovery policies before the quakes; however, the structure of CERA, combined with a faltering CCC, might overlook the opportunity for higher levels of community engagement. This section will consider the potential for, and progress of, community engagement in disaster recovery in Canterbury.

CERA's structure was initially criticised for being top-down, centralised and bureaucratic, in contrast with the ideals of the recovery management being bottom-up, decentralised and community led. CERA's arrangements were described as having the appearance of community engagement but the reality of ministerial control. CERA's draft recovery strategy supports the holistic framework for recovery advocated by the MCDEM, which places the community at the centre of all the task groups. Weak implementation, however, could undermine international lessons about the value of community engagement in recovery.

The Christchurch community forum design may compromise effective engagement, as its members may struggle to represent the views of the city's 400000 people. Confusion about how the forum can influence the minister and what its role is generally - according to the CCC (2011), its role is unclear 
in the draft recovery strategy-diminishes the Government's assertion that it would encourage meaningful participation by community representatives in the recovery process.

The scale of community consultation by the CCC has improved recently. The community contributed 106000 ideas to help inform the direction for the draft plan, generated from various initiatives and conversations. The CCC worked closely with Ngāi Tahu, Environment Canterbury and CERA during the development of the draft plan; however, there is still some criticism that the $\mathrm{CCC}$ is not generating higher levels of community engagement.

The community forum's 3 November 2011 meeting notes indicate that the CCC understands its people less than Waimakariri or Selwyn councils (CERA Community Forum 2011). This is probably a function of the CCC's size, but also reflects the perceived unwillingness in the CCC to delegate to the community.

A community's recovery may demand more engagement than would normally be expected; however, it was not clear whether the views expressed in eight CERA community workshops influenced the preparation of the recovery strategy. While there was a commitment in the draft strategy to engage and collaborate in the recovery, the draft recovery strategy does not define how this will occur. Submissions on the strategy suggest CERA should more proactively encourage community engagement at every stage-planning, implementation, monitoring and review - and at levels beyond consultation.

Much of the literature supporting community engagement seems to 'assume that the state will be both willing and able to accept post-disaster input from communities who are themselves willing and able to participate in the recovery process' (Vallance 2010:20). This assumption may not be valid. Vallance (2011) suggests recovery authorities struggled to connect adequately with affected communities for some time in Canterbury. In early February 2012, only 79 written comments on the draft central city plan had been received (The Press 2012). The reasons for the difference between these numbers and the 106000 ideas generated for the creation of the same plan and the number of protestors who demonstrated over the pay increase for the council's CEO are matters for further study. Community engagement is, however, more suited to the recovery phase than the response phase. It has yet to be seen whether the recovery will truly benefit from comprehensive community engagement.

\section{Discussion}

New Zealand has four options to govern future large-scale disasters. First, the pre-quake legislative arrangements could be reinstituted. Second, a CERA- 
style model could be replicated. Third, significant amendments to the prequake framework could be made. Fourth, there could be a new and completely different model for disaster management and recovery.

The difficulties with the first two options have been indicated above, and the fourth would be difficult at the design and legislative stages. The pre-quake framework had many strengths, with most weaknesses related to the recovery phase. So there is a good case for amending the pre-quake framework for recovery after exceptional events.

\section{Amendments to the Framework for Recovery}

\section{CDEM}

New provisions should be added to the CDEM Act to support long-term recovery management after a state of emergency has been dissolved. Rotimi (2010) notes that this would require a more proactive role by the MCDEM. Furthermore, recovery planning and management should be strengthened across all involved sectors.

That enabling powers for long-term recovery were not considered prior to the quakes was an oversight. This must be addressed with due regard to democratic and constitutional norms.

The position of a national recovery coordinator to facilitate recovery planning and management initiatives should be made permanent (Rotimi 2010) to reflect the important, long-term nature of recovery management after a disaster.

In large-scale disasters central government intervention may always be necessary, as city councils probably lack the capability and resources to meet needs in the years following a disaster. A small permanent agency, having recovery powers like those of CERA, could be considered. This could involve extending the role of the MCDEM into the recovery phase; however, any such agency is likely to be inactive for long periods and could attract problems when clarifying who pays for localised disaster recovery. The MCDEM and other agencies involved in recovery could have a scale-up plan that would be triggered in a Canterburyscale scenario.

If local authorities are to manage long-term recovery, they may require extra powers to enable recovery activities. Furthermore, if there is substantial damage to council-owned land and investments, as well as population flight, how will councils fund the recovery? 
The events in Christchurch indicate that disasters will overwhelm councils. Rotimi (2010) recommends the development of memoranda of understanding between agencies. These should outline how recovery can be achieved through collaborative efforts.

Rotimi recommends greater alignment of the CDEM Act with the RMA and Building Act so all recovery-related provisions and activities avoid conflicting implementation of recovery tasks. The amendments to legislation provided by orders-in-council provide policymakers with a number of potential areas that will need to be aligned and addressed. Some of these issues were considered in evidence provided to the Canterbury Earthquakes Royal Commission.

Any change to legislation should take best-practice literature into account. The current devolved model of recovery assumes local authorities know their communities best, which gives the best opportunity for community engagement; however, Christchurch shows that the institutional capacity of local authorities after major disasters will be overwhelmed, which is likely to be true both for institutional capacity in general and their ability to engage with their communities. Also, opportunities for higher-level engagement may be discouraged. There are calls in Christchurch for recovery actors to move beyond tokenistic approaches to community consultation and embrace higher levels of community engagement. If people do not feel involved in the future of their city then those who can might leave.

A significant focus of disaster management is on planning for recovery, but how do you plan for the unexpected? This question should be studied. Institutional arrangements ought to be flexible enough to deal with a large range of disasters of different scales, as well as with emergent policy issues.

The people of Christchurch will largely have to work within the institutional arrangements that currently exist; however, they should be able to have a substantial say in their future.

\section{Resource Management Act}

The $R M A$ 's procedural requirements and other provisions for wide consultation might hinder fast recovery. Rotimi proposed the scale of consultation and public notification be limited to permit a speedy approval process. Procedural requirements can delay essential works, as the complete collapse of seven previously damaged heritage buildings in the February quake showed. Approval to demolish them required an engineering report and resource consent, which would take months. In February the facades of the buildings collapsed, killing 12 people. Demolition of buildings is now allowed if they pose an immediate danger to human safety. Heritage protection remains an issue for legislators, especially in balancing the need for public consultation with the need for safety. 
Future-Proofing the State

The RMA should be amended but procedures should not hinder the purpose of sustainable management of resources. The Government intends to amend the $R M A$ to give greater weight to managing the risks of natural hazards. This should include a review of consents given to land that is prone to issues like liquefaction.

\section{The EQC}

A 2009 review of the EQC suggested it was not prepared for a major national disaster. Furthermore, there was widespread confusion about what its role would be, with the Government expecting agencies like the EQC to be more 'directly involved in the response and recovery than their mandate and capability allows' (Heather 2011). This led to the EQC having more contact with private insurers, and in case of a major quake aiming to settle 80000 claims in 12 months.

The EQC was overwhelmed by the scale of the Canterbury quakes. In February 2012, there were huge disparities between the approaches of private insurance companies and the EQC in assessing the damage to homes. For example, private insurers' policies say that they will reinstate the property 'as new'. The EQC Act provides that they will reinstate the property 'substantially the same as when new'. This disparity could mean the difference between repair and demolition (Wright 2012).

Changes to the EQC Act should address these issues. The EQC should plan for multiple events and large numbers of claims. Its financial viability will also need to be examined. The EQC levy paid annually by homeowners has already tripled. EQC advice to the incoming minister in November 2011 suggested changes, including removing contents insurance cover, introducing variable premiums depending on house size or hazards risk, automatic adjustment of premiums and payout caps, and increasing the excess on claims.

With the costs of damage rising, the viability of the EQC model will become difficult, especially given the government guarantee to meet the EQC's shortfall. As the cost of insurance in disaster-prone areas becomes increasingly unaffordable, it is likely more people will choose not to insure their homes and EQC cover will not apply. In this situation, the problem of moral hazard arises, particularly if the public expects the Government will take on residual risk. Additionally, as outlined earlier, provisions in the EQC Act allow for cover not to apply to high-risk land or notified earthquake-prone buildings. A stricter application of the Act in the future may be harsh, but fiscally necessary. 


\section{Conclusion}

An evaluation of the pre-quake framework for recovery now confirms that the legislative support for long-term recovery was inadequate. The new governance arrangements following the quakes had flaws. The legislation addressing recoveries in both cases were rushed because the Government was dealing with disasters of unprecedented scale.

The disasters raise several wider implications. How is the cost of the Canterbury quakes and the role of government altering expectations and incentives for the future? Will we become less insured and does this effectively increase the fiscal risk for governments? Will local governments expect future recovery projects will be centrally planned as Canterbury is? How will the 'shelf plan' for the next major event balance collaboration with executive management? How does that affect the democratic deficit in local government? How important is it to have an effective legislative framework in place when future governments will be able to legislate to meet the needs of the disaster?

The role of councils leading long-term recovery needs further evaluation. While councils may theoretically provide the opportunity for effective community engagement, their capability to lead recovery is questionable.

New Zealand's framework for recovery needs to be future-proofed. Though we cannot prevent most natural disasters, we can try minimising their impact and create governance arrangements to maximise recovery. The process for learning from disaster and recovery should consider not only institutional understandings, but also citizen expectations of what should be done better next time. Crucially, we must find ways to imbed learning from disasters into institutional memory.

\section{References}

Bollard, A. and Ranchhod, S. 2011. Economic impacts of seismic risk: lessons for Wellington, Speech delivered to the Rotary Club of Wellington and Victoria University of Wellington Organisational Effectiveness in Times of Seismic Risk Conference, Wellington.

Canterbury Earthquake Recovery Authority (CERA). 201la. Briefing to the Incoming Minister (Christchurch: Canterbury Earthquake Recovery Authority).

Canterbury Earthquake Recovery Authority (CERA). 2011b. Draft Recovery Strategy for Greater Christchurch (Christchurch: Canterbury Earthquake Recovery Authority). Available from: <http://cera.govt.nz/sites/cera.govt. nz/files/common/draft-recovery-strategy-for-greater-christchurch.pdf $>$. 
Canterbury Earthquake Recovery Authority (CERA) Community Forum. 2011. Minutes of the Meeting of the CERA Community Forum, 3 November (Christchurch: Canterbury Earthquake Recovery Authority). Available from: $<$ http://cera.govt.nz/sites/cera.govt.nz/files/common/community-forummeeting-notes-20111103.pdf>.

Christchurch City Council (CCC). 2011. Draft Recovery Strategy Comments from Organisations (Christchurch: Christchurch City Council). Available from: $<$ http://cera.govt.nz/sites/cera.govt.nz/files/common/draft-recovery-strategycomments-from-organisations.pdf $>$.

Christchurch City Council(CCC). 2012. Council streamlines consent process, Media release (Christchurch: Christchurch City Council). Available from: <http:// www.ccc.govt.nz/thecouncil/newsmedia/mediareleases/2012/201202032. $\operatorname{aspx}>$.

Cowan, H. and Simpson, I. 2011. Planning for disasters and responding to unforseen complexity: the first large test for the New Zealand Earthquake Commission, Presentation to 12th Biennial Aon Benfield Hazards Conference, Surfers Paradise, Qld.

Dalziel, L. 2011. Turning disaster into opportunity, Keynote address, Australian and New Zealand Institute of Insurance and Finance Conference, Auckland.

Department of Labour (DOL). 2011. Employment Opportunities in Canterbury, December (Wellington: Government of New Zealand). Available from: <http:// www.dol.govt.nz/publications/research/employment-opportunitiescanterbury/eoc.pdf $>$.

Doherty, E. 2011. Economic Effects of the Canterbury Earthquakes, Parliamentary Library Research Paper (Wellington: Government of New Zealand).

Geddis, A. 2011. An open letter to New Zealand's people and their Parliament, 28 September (North Dunedin: Faculty of Law, University of Otago).

Geonet. 2011. 'Christchurch Badly Damaged by Magnitude 6.3 Earthquake', GNS Science, 22 February. Available from: <http://geonet.org.nz/news/feb2011-christchurch-badly-damaged-by-magnitude-6-3-earthquake.html $>$.

Government of New Zealand. 2010. Canterbury Earthquake Response and Recovery Bill 2010 (Wellington: Government of New Zealand). Available from: <http:// www.legislation.govt.nz/bill/government/2010/0215/latest/whole.html>.

Government of New Zealand. 2011a. Cabinet Paper 1: Proposed Governance Arrangements (Wellington: Government of New Zealand). Available from: $<$ http://cera.govt.nz/sites/cera.govt.nz/files/common/cabinet-paper-1proposed-governance-arrangements-march-2011.pdf $>$. 
Government of New Zealand. 2011b. Cabinet Paper 2: Proposed Powers-Annex 2-Regulatory Impact Statement (Wellington: Government of New Zealand). Available from: <http://cera.govt.nz/sites/cera.govt.nz/files/common/cabinetpaper-2-proposed-powers-annex-2-regulatory-impact-statement-march-2011. pdf $>$.

Government of New Zealand. 2012. Summary of Crown Observer Proposal (Wellington: Government of New Zealand). Available from: <http://www. beehive.govt.nz/sites/all/files/Crown_Observer_Proposal.pdf>.

Grant, J. 2011. 'One Year On - The Future of Earthquake Insurance for Residential Properties', interest.co.nz, 5 September. Available from: <http://www. interest.co.nz/insurance/55212/one-year-future-earthquake-insuranceresidential-properties $>$.

Greenhill, M. 2012. 'Life on the Edge of a Raw Nerve', stuff.co.nz, 17 January. Available from: <http://www.stuff.co.nz/national/christchurchearthquake/6266653/Life-on-the-edge-of-a-raw-nerve $>$.

Heather, B. 2011. 'Extent of Damage Never Imagined', stuff.co.nz, 4 September. Available from: <http://www.stuff.co.nz/national/christchurch-earthquake/5559040/Extentof-disaster-never-imagined $>$.

International Association for Public Participation (IAP2). 2004. IAP2 Public Participation Spectrum (Wollongong, NSW: IAP2). Available from: <http://www.iap2.org.au/sitebuilder/resources/knowledge/asset/files/36/ iap2spectrum.pdf $>$.

McCrone, J. 2011. 'Over the Top?', The Press, 23 April. Available from: < http:// www.stuff.co.nz/the-press/news/christchurch-earthquake-2011/4920414/ Over-the-top $>$.

Millen, D. 2011. Deliberative Democracy in Disaster Recovery: Reframing Community Engagement for Sustainable Outcomes (Sydney: University of Western Sydney).

Ministry of Civil Defence and Emergency Management (MCDEM). 2005a. Focus on Recovery: A Holistic Framework for Recovery in New Zealand (Wellington: Government of New Zealand).

Ministry of Civil Defence and Emergency Management (MCDEM). 2005b.New Zealand's Response to the 1994 Yokohama Strategy and Plan of Action for a Safer World: National Information Report, United Nations International Strategy for Disaster Reduction (Geneva: UNISDR). Available from: < http:// www.unisdr.org/2005/wcdr/preparatory-process/national-reports/NewZealand-report.pdf $>$. 
Future-Proofing the State

Ministry of Civil Defence and Emergency Management (MCDEM). 2008. National Civil Defence Emergency Management Strategy (Wellington: Government of New Zealand).

Ministry of Civil Defence and Emergency Management (MCDEM). 2009a. Guide to the National Civil Defence Emergency Management Plan 2006, Rev. edn (Wellington: Government of New Zealand). Available from: <http://www. civildefence.govt.nz/memwebsite.nsf/Files/The-Guide-2009-revision/\$file/ summary-of-sections.pdf $>$.

Ministry of Civil Defence and Emergency Management (MCDEM). 2009b. Section 25. Recovery (Wellington: Government of New Zealand).

Ministry of Civil Defence and Emergency Management (MCDEM). 2010. Community Engagement in the CDEM Context-Best Practice Guideline for Civil Defence Emergency Management Sector (Wellington: Government of New Zealand).

New Zealand Press Association (NZPA). 2011. 'Christchurch Quake Could Cost \$30b', 3news.co.nz, 11 March. Available from: <http://www.3news.co.nz/ Christchurch-quake-could-cost-30B/tabid/423/articleID/201875/Default. $\operatorname{aspx}>$.

Rotimi, J. 2010. An examination of improvements required to legislative provisions for post disaster reconstruction in New Zealand, PhD Thesis (Christchurch: University of Canterbury).

The Press. 2012. 'Recovery Plan Attracts Fewer than 20 Comments', The Press, Last updated 1 February 2012. Available from: <http://www.stuff.co.nz/thepress/news/christchurch-earthquake-2011/6344439/Recovery-plan-attractsfewer-than-20-comments>.

Treasury. 2011. Budget Economic and Fiscal Update (Wellington: Government of New Zealand). Available from: <http://www.treasury.govt.nz/budget/ forecasts/befu2011>.

United Nations Development Programme (UNDP). 2006. Post-Disaster Recovery: Guiding Principles (New York: UNDP Bureau for Crisis Prevention and Recovery-Disaster Reduction Unit). Available from: <http://www. undp.org/cpr/disred/documents/publications/regions/america/recovery_ guidelines_eng.pdf $>$.

United Nations International Strategy for Disaster Reduction (UNISDR). 2005. Governance: Institutional and Policy Frameworks for Risk Reduction (Geneva: UNISDR). Available from: <http://www.unisdr.org/2005/wcdr/thematicsessions/WCDR-discussion-paper-clusterl.pdf $>$. 
Vallance, S. 2011. 'Early Disaster Recovery: A Guide for Communities', Australian Journal of Disaster Recovery \& Trauma Studies, 2011-12:19-25.

Wright, M. 2012. 'EQC, Insurers to Join Forces on Assessments', stuff.co.nz, Last updated 1 February 2012. Available from: <http://www.stuff.co.nz/ national/christchurch-earthquake/6344433/EQC-insurers-to-join-forces-onassessments $>$. 
This text taken from Future-Proofing the State: Managing Risks, Responding to Crises and Building Resilience, edited by Jonathan Boston, John Wanna, Vic Lipski and Justin Pritchard, published May 2014 by ANU Press, The Australian National University, Canberra, Australia. 